\title{
A Response to Wiebe Koopal's Review of Inhuman Educations: Jean-François Lyotard, Pedagogy, Thought
}

\author{
Derek R. Ford ${ }^{1}$
}

Accepted: 13 April 2021 / Published online: 27 July 2021

(C) The Author(s), under exclusive licence to Springer Nature B.V. 2021

I was recently on a philosophy of education panel about navigating grad and post-grad life during COVID-19. A student about to defend asked ways to celebrate their defense, and I said the defense is the celebration. When else do you have 5 people read your work seriously and ask you questions about it for a few hours? That's a highlight for any academic! The other moments are when your books or articles elicit reviews and responses, but only in some of those do the authors really take the work seriously. I sincerely thank Wiebe Koopal for doing so; for highlighting what they found useful and helpful, what they found lacking, and then, most importantly, building on the book to do and think new things in and with it.

That, for me, is what Lyotard's pedagogy is about: propositions and questions, fragments and fables. The review moved me to another state of wonder, a state I always find when I engage Lyotard. I appreciate the fact that Koopal picked on my "evident passion" and on the "writing style excelling in expressivity, nuance, and accessibility." That was my main goal with the book: to make others excited about Lyotard, to present him accessibly without annihilating the essence of his thought - which is literally inaccessible or at the limits of accessibility. Rather than spend time on the Koopal's endorsements, I want to respond to his critiques and propositions, clarifying without (hopefully) merely retreating and instead taking up his proposition and example.

The first criticism is that "the many dichotomies shaping the book's discourse" can leave "concretely situated practices abstract." The second criticism is of my "lack of attention to education as a public issue" and, relatedly, my "overall stress on its 'initiatory', 'private', and 'sectarian' aspects. To me there is something to both of these criticisms, but I hope to make them a bit finer-and the reader can take or leave them as they wish. The dichotomy running throughout the book is that between the two inhuman educations: that of the system and that of the infant. The system is an endless developmental process without any justification other than more development. This is the dominant understanding of education in which educators are tasked with transitioning infants into adults-those who can't speak into those who can. The inhumanity of infancy, on the other hand, is a permanent reservoir of resistance, it's a biological state but one that remains with us as an inhumanity that defines our humanity, that erupts from time to time. In this sense, it isn't exactly "an ever-retreating abyss within everything," but rather an undeniable ontological

Derek R. Ford

derekford@depauw.edu

1 DePauw University, 218 Harrison Hall, 7 E. Larabee St., Greencastle, IN 46135, USA 
experience we all have when, for example, we can't speak words and can instead only voice our affect with muted sounds. The pedagogical question is how we orient ourselves to it: do we let it happen, or do we reduce it to meaning and signification (even if we do that endlessly)? Lyotard was no dialectician, of course, and it's interesting that I hadn't even realized the dichotomies I find in his work. It might be my own reading, however, my own love of binaries and their explanatory and problematizing potential. And it might be the only way I can really make some sense of Lyotard. These show up differently as I explore the different pedagogical practices Lyotard engaged — and which I read Lyotard's pedagogical thought through: reading, writing, voicing, and listening.

I'm glad Koopal appreciated this move to situate Lyotard's pedagogical philosophy within practices and I'm just as glad he isn't satisfied with how I did it. He finds that had I been better at this it would "be generous towards the less informed reader" and "help take 'the edge off' the infancy/system dichotomy." I'm even more excited that he presents an archetype of such a practice later on.

Before moving there, however, there is one last clarification to offer. It's one that Joris Vlieghe's (2021) excellent afterword to the book missed a bit, and my guess is others might miss it to. It has to do with the public and private. Koopal worries that I don't provide "another, more pedagogical notion of the public." Koopal is right that inhuman educations of infancy always act within and upon developmental systems. I think there's something here, but I get worried at Koopal's desire to make readers "reflect on the concrete circumstances and conditions that make such non-systemic possibility publicly effective." The private and the public, for Lyotard (in my book anyways), who takes it from Nina Berberova, are specific conceptions. The private life isn't individual; in fact, it's where Berberova and her lover met. For Lyotard, it's where we go alone or together to figure out what we can't say.

This is different from the public life, the democratic life that we all see-that we read, speak, articulate, and so on. Both are necessary, but the danger is that the line between the two will fade and that the public will take over the secret. This has, I think, happened in many ways. Think about the need to say everything that is unsaid; to put your most obscure thoughts and desires into text; to share your secret journals with the world. As I quote from Lytoard: "Publish or perish!" "If you are not public," Lyotard says, "you disappear; if not exposed as much as possible, you don't exist. Your no-man's-land is interesting only if expressed and communicated" (Cited in Ford 2021, 29-30). This is the terror of democracy: it produces us as subjects who are compelled to express, and these expressions then serve as raw materials in the system's expansion. It leaves no room for the secret.

I'm sympathetic to these critiques and excited by them. I'll leave it up to scholars of Lyotard to say whether these critiques are of Lyotard or my take on Lyotard. But in general, I find Lyotard's presence in my own living, thinking, studying, teaching, and acting one not of withdraw but of momentary rupture: a sudden, "yeah, why is that the case?" Lyotard never stops asking the most fundamental questions in new and relevant ways.

These two critiques, which each have their merits, lead Koopal to offer Deleuze's (2000) apprenticeship with Proust as a concrete manifestation of infancy, a concrete practice we can take up in our own way. "The Proustian practice of music-educational ekphrasis," he writes, "calls for continuously repeated and shared description of a sign-any music experience-in creative new situation correspondences that may always shift with the description itself." This is valuable because there is room for infancy made public. Yet my concern is that the desire to endlessly describe any sign is precisely what the inhuman system thrives on. It's definitely what contemporary capitalism thrives on: our endless 
comments, retweets, likes, blog posts, etc.... (see Ford 2018). The other option for Koopal is that we enter the void, "the ultimate, infantile abyss of its inaudible, "mutic" timbre.

As an organizer, Koopal's dissatisfaction resonates with me. That's why the book is my attempt to read Lyotard in my own way but without evaluating or assessing his work. For me, it's important that these be approached, however, as developmental extensions. I wrote the book from an eruption of infancy within my own developmental impulses. The lack of concrete practices, then, is a necessary feature of the work and its elliptical nature. The ellipsis enacts an infinite stupor that disrupts the sentence or thought, and it doesn't represent but performs it. When it appears at the end of a list, for example, it opens the list up to the unforeseen. "What else is included in the list?" "Why wasn't it included?" "On what basis was the exclusion justified?" It also works retroactively to render the list itself uncertain. "What exactly is the relation between the listed items?" The inability to confirm even the basest links exists in any list, but is heightened with the ellipsis. It's a moment of pedagogical inadequacy that returns the developmental writing to infancy and inaudibility.

The inaudible and secret community, however, might be key to the fight for a new and different future. Andy Merrifield (2020) suggests as much in his recent book on Marx and Capital, where he paraphrases Rimbaud, writing that "truth will have to go underground.... Ours is a similar age. To trace out any hope of its recovery, Marxists need to organize underground, follow Old Mole of old, assemble in bedsits, in sunken basements, maybe in communal squats, somewhere cheap, somewhere far away. Or nearby" (162). This explains the right-wing's quest to expose every communist agent, plot, etc. They're agents of the system, not of infancy.

We won't find any of this in Lyotard, which is one reason why I only drift toward and away from Lyotard throughout my life. I'm a communist, and one dedicated to that struggle. But the communism I fight for is one where the secret life flourishes, where the inarticulable infancy of the world does rupture the system, creating new orders of being in space and time, new social organizations, and more. Elements of such a communist world are present in different stages across the globe and throughout time (see Ford 2017). Lyotard's position on the system was agnostic. Mine is partisan. I find Lyotard gives us valuable openings toward this resistance. In this sense, the concrete practice I offer throughout each pedagogical form is the ellipses... Thanks, Koopal, for putting more in there.

\section{References}

Deleuze, G. 2000. Proust and signs (trans: Howard, R.). Minneapolis: University of Minnesota Press.

Ford, D.R. 2017. Making marxist pedagogy magical: From critique to imagination, or, how bookkeepers set us free. Critical Education 8 (9): 1-13.

Ford, D.R. 2018. Queer communist study: Queer communist study: The sinthomostudier against the capitaldebt-learning regime. Journal of Curriculum \& Pedagogy 15 (1): 8-23.

Ford, D.R. 2021. Inhuman educations: On Jean-François Lyotard, pedagogy and thought. Leiden, Boston: Brill.

Merrifield, A. 2020. Marx dead and alive: Reading capital in precarious times. New York: Monthly Review Press.

Vlieghe, J. 2021. Afterword: Towards a post-human approach to (in)humanity: Reflections on Derek Ford's Inhuman Educations. In Inhuman educations: Jean-François Lyotard, pedagogy, thought, ed. D.R. Ford, 69-81. Leiden: Brill.

Publisher's Note Springer Nature remains neutral with regard to jurisdictional claims in published maps and institutional affiliations. 